\title{
Thalassomonas viridans gen. nov., sp. nov., a novel marine $\gamma$-proteobacterium
}

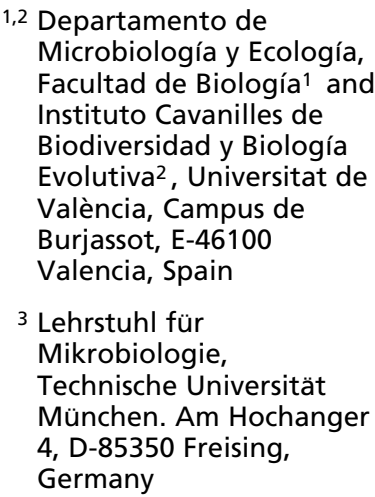

\author{
M. C. Macián, ${ }^{1,2}$ W. Ludwig, ${ }^{3}$ K. H. Schleifer, ${ }^{3}$ E. Garay ${ }^{1,2}$ \\ and M. J. Pujalte ${ }^{1,2}$ \\ Author for correspondence: M. J. Pujalte. Tel: +34 96 3983142. Fax: +34963983099. \\ e-mail:maria.j.pujalte@uv.es
}

\begin{abstract}
A new genus and species are proposed for two halophilic, strictly aerobic, chemo-organotrophic, marine bacterial strains. These bacteria are Gramnegative, motile rods isolated from oysters cultivated off the Mediterranean coast at Valencia (Spain). They produce green/blue-green diffusible pigment. The G+C content of the DNA of the proposed type strain (XOM25') is $48.4 \mathrm{~mol} \%$. A $16 \mathrm{~S}$ rRNA gene sequence analysis of the two strains has shown that the new isolates represent a branch within the $\gamma$-Proteobacteria, close to the genus Colwellia. The type species of the new genus is Thalassomonas viridans gen. nov., sp. nov., with the type strain $\mathrm{XOM}^{\mathrm{T}} 5^{\mathrm{T}}$ (=CECT $5083^{\mathrm{T}}=\mathrm{DSM}^{\mathrm{C}}$ 13754').
\end{abstract}

Keywords: $\gamma$-Proteobacteria, marine bacteria, Thalassomonas viridans gen. nov., sp. nov., green pigment, $16 \mathrm{~S}$ rDNA phylogeny

\section{INTRODUCTION}

Most of the readily culturable, heterotrophic, marine bacteria belong to the $\gamma$-Proteobacteria, a branch that includes the fermentative genera Vibrio, Photobacterium, Moritella and Colwellia, the non-fermentative or weakly fermentative facultative anaerobes Shewanella and Ferrimonas and strict aerobes distributed among the halophilic/halotolerant genera Alcanivorax, Alteromonas, Cycloclasticus, Fundibacter, Glaciecola, Halomonas, Idiomarina, Marinobacter, Marinomonas, Marinospirillum, Microbulbifer, Neptunomonas, Oceanospirillum and Pseudoalteromonas and some authentic Pseudomonas species.

Of these genera, at least 22 species are known to produce pigmented colonies or diffusible compounds ranging in colour from yellow/orange (Cycloclasticus pugetii, Pseudoalteromonas aurantia, Pseudoalteromonas citrea, Pseudoalteromonas peptidolytica, Pseudoalteromonas piscicida, Vibrio fischeri, Vibrio logei) to red (Colwellia psychrerythraea, Glaciecola punicea, Pseudoalteromonas bacteriolytica, Pseudoalteromonas denitrificans, Pseudoalteromonas rubra, Vibrio gazogenes), pink (Glaciecola pallidula, some

The GenBank/EMBL accession numbers for the $16 \mathrm{~S}$ rRNA sequences of Thalassomonas viridans CECT 5082 and CECT $5083^{\top}$ are AJ294747 and AJ294748, respectively. shewanellae), violet/yellow (Pseudoalteromonas luteoviolacea), brown/black (Marinomonas mediterranea, Neptunomonas naphthovorans, Pseudoalteromonas nigrifaciens, Shewanella colwelliana, Vibrio nigripulchritudo) and green (Oceanospirillum linum, Pseudoalteromonas tunicata). Pigment production seems to be involved in antibiotic/antilarval activities (Holmström \& Kjelleberg, 1999; Holmström et al., 1992; Lemos et al., 1991) and autotoxicity (Baumann et al., 1984). It is possible that the active components are produced by the same pathway or by a branch of the pathway leading to pigment production (Holmström et al., 1998).

Two strains of halophilic, strictly aerobic bacteria producing a deep green to blue-green, diffusible and unstable pigment were isolated from oysters close to the coastal area of Valencia, Spain. In a previous numerical taxonomic study (Ortigosa et al., 1994), strains XOM5 and XOM $25^{\mathrm{T}}$ were phenotypically characterized and remained as a clearly isolated, unique phenon after clustering. They showed a marked loss of viability within a few days in culture, and were deposited at the Colección Española de Cultivos Tipo as CECT 5082 and CECT $5083^{\mathrm{T}}$ and at the Deutsche Sammlung von Mikroorganismen und Zellkulturen (DSMZ) as DSM 13753 and DSM 13754 ${ }^{\mathrm{T}}$, respectively.

We have characterized both strains by determining the complete sequence of the 16S rRNA genes, the $\mathrm{G}+\mathrm{C}$ 
content of the DNAs and cultural, physiological and biochemical features. Their phenotypic characteristics and the results of phylogenetic analyses indicate a moderate relationship to the genus Colwellia (within the $\gamma$-Proteobacteria) that is sufficiently distant to constitute a new genus.

\section{METHODS}

Bacterial strains and growth conditions. Two environmental strains (XOM5 and XOM25 $5^{\mathrm{T}}$ ) that constituted phenon 29 in the previous study by Ortigosa et al. (1994) were isolated from Mediterranean oysters, on Marine agar 2216 (MA; Difco) plates. Cultures were maintained on semi-solid MA stabs at room temperature and were also suspended in filtered, aged, sterile sea water at room temperature in the dark. They were grown routinely on MA or Marine broth 2216 (MB; Difco) at $24-26{ }^{\circ} \mathrm{C}$.

Phenotypic characterization. The phenotypic profiles of the two environmental strains were determined. Cultivation was done at $24-26^{\circ} \mathrm{C}$. Pigment production, swarming and colony morphology were examined after growing the cells on MA plates. Cell morphology and motility were examined on wet mounts by phase-contrast microscopy. The flagellar arrangement was examined after staining MA-grown cells by the method of Heimbrook et al. (1989). The Gram reaction was determined by using the $\mathrm{KOH}$ lysis method of Buck (1982). The ability to reduce nitrate to nitrite was tested in nitrate broth plus $1 \%(\mathrm{w} / \mathrm{v}) \mathrm{NaCl}$ (Smibert \& Krieg, 1994) and in denitrification medium (Baumann \& Baumann, 1981). The oxidation/fermentation test was performed in $\mathrm{O} / \mathrm{F}$ medium (Difco) rehydrated with halfstrength artificial sea water (ASW) plus $1 \%(\mathrm{w} / \mathrm{v})$ glucose, glycerol or $N$-acetylglucosamine. Tests for Thornley's arginine dihydrolase and nutritional screening on basal medium plates, as well as on Baumann's basal medium supplemented with $0 \cdot 1 \mathrm{~g}$ yeast extract $1^{-1}$, were performed by using methods described previously (Baumann et al., 1984). The alkalinization/decarboxylation of arginine, lysine and ornithine was determined in Møller broth (decarboxylase medium base; Difco) and the oxidase test and growth on thiosulfate/citrate/bile salts/sucrose (TCBS) agar were performed using the methods of Lee \& Donovan (1985). The catalase test ( 10 vols $\mathrm{H}_{2} \mathrm{O}_{2}$ ) was performed according to Smibert \& Krieg (1994). Indole production was tested on MB after $48 \mathrm{~h}$. Hydrolysis of casein, gelatin, Tween 80, lecithin, starch, sodium alginate and agar was tested according to Ortigosa et al. (1994). The range of salinity supporting growth of the strains was tested by using five media: (i) salt-tolerance broth [STB: 1\% (w/v) tryptone, $0 \cdot 3 \%(\mathrm{w} / \mathrm{v})$ yeast extract with $0,2,4,6,8$ and $10 \%(\mathrm{w} / \mathrm{v})$ $\mathrm{NaCl}$; (ii) STB with 2 or $4 \%$ (w/v) $\mathrm{NaCl}$ and $0.1 \%(\mathrm{w} / \mathrm{v})$ $\mathrm{MgCl}_{2}$; (iii) STB with $2 \%(\mathrm{w} / \mathrm{v}) \mathrm{NaCl}$ and $0 \cdot 1 \%(\mathrm{w} / \mathrm{v})$ $\mathrm{CaCl}_{2}$; (iv) $\mathrm{STB}$ with $2 \%(\mathrm{w} / \mathrm{v}) \mathrm{NaCl}$ plus $0 \cdot 1 \%(\mathrm{w} / \mathrm{v})$ $\mathrm{MgCl}_{2}$ and $0 \cdot 1 \%(\mathrm{w} / \mathrm{v}) \mathrm{CaCl}_{2}$; (v) $\mathrm{MB}$ supplemented with enough $\mathrm{NaCl}$ to achieve $4,6,8$ and $10 \%(\mathrm{w} / \mathrm{v})$ total $\mathrm{NaCl}$. Growth at different temperatures was tested in both liquid (MB) and solid (MA) media at $4{ }^{\circ} \mathrm{C}(7 \mathrm{~d})$ and at 13, 20, 28, 30,37 and $40^{\circ} \mathrm{C}$. Sulfite oxidation was tested on solid medium by following the method described by González et al. (1999).

Cellular fatty acid analysis. For the analysis of whole-cell fatty acids, cells were grown for $24 \mathrm{~h}$ at $28^{\circ} \mathrm{C}$ on MA and approximately $40 \mathrm{mg}$ bacterial cells was harvested from the Petri dish. Analysis of the fatty acids by GLC was performed at the DSMZ by using a method described previously (Kämpfer \& Kroppenstedt, 1996).

DNA base composition. The $\mathrm{G}+\mathrm{C}$ content (mol \%) of genomic DNA was determined from the midpoint value of the thermal denaturation profile (Marmur \& Doty, 1962) obtained with a model UV-Vis 551S spectrophotometer (Perkin-Elmer) at $260 \mathrm{~nm}$. This instrument was programmed for temperature increases of $1.0{ }^{\circ} \mathrm{C} \mathrm{min}^{-1}$. The $\mathrm{G}+\mathrm{C}$ content of reference DNA from Escherichia coli NCTC $9001^{\mathrm{T}}$ was taken to be $51 \mathrm{~mol} \%$ (Owen \& Pitcher, 1985).

Extraction of genomic DNA and amplification and sequencing of rDNA. Isolation of genomic DNA was carried out according to Lewington et al. (1987). The genomic DNA of bacterial strains was used for the in vitro amplification of almost full-length 16S rRNA gene fragments by using the following primer set: 5'-AGAGTTTGATYMTGGCTCAG-3' (E. coli positions 8-27; Brosius et al., 1981) and 5'CAKAAAGGAGGTGATCC-3' (positions 1529-1546). Amplifications were performed with a Hybaid OmniGene temperature controller (MWG-Biotech) as follows. The following components were added to a $0.2 \mathrm{ml}$ reaction tube: $1 \mu \mathrm{l}(0 \cdot 1-1 \mu \mathrm{g})$ genomic DNA solution, $50 \mathrm{pmol}$ each of the appropriate primers, $10 \mathrm{mM}$ dNTP mix (Qiagen), $10 \mu 110 \times$ PCR buffer [Tris/ $\mathrm{HCl},\left(\mathrm{NH}_{4}\right)_{2} \mathrm{SO}_{4}, 15 \mathrm{mM} \mathrm{MgCl} ; \mathrm{pH}$ 8.7] and $1.5 \mathrm{U}$ thermostable Taq polymerase (Qiagen). The total volume was adjusted to $100 \mu \mathrm{l}$ with sterile water. After initial heating at $94^{\circ} \mathrm{C}$ for $3 \mathrm{~min}, 30$ cycles consisting of denaturation at $94{ }^{\circ} \mathrm{C}$ for $30 \mathrm{~s}$, annealing at $52^{\circ} \mathrm{C}$ for $30 \mathrm{~s}$ and extension at $72^{\circ} \mathrm{C}$ for $1 \mathrm{~min}$, increasing by $5 \mathrm{~s}$ per cycle, were performed, followed by a final elongation step at $72{ }^{\circ} \mathrm{C}$ for $10 \mathrm{~min}$. The resulting PCR products were purified using the QIAquick PCR purification kit (Qiagen) and sequenced using a LICOR automated sequencer (MWG Biotech). Cycle-sequencing protocols based upon the chain-termination technique were applied using the Thermo Sequenase fluorescent labelled primer cycle-sequencing kit of Amersham.

Sequence data analysis. Sequences were added to the $16 \mathrm{~S}$ rRNA sequence databases of the Technical University of Munich by using the program package ARB (Ludwig \& Strunk, 1997). ARB tools were used for automated sequence alignment. The alignment was checked by eye and corrected manually using the sequence editor ARB_EDIT. Phylogenetic analyses were performed by applying maximum-parsimony (full dataset of 20000 sequences, ARB, parsimony), distancematrix (all available $\gamma$-proteobacteria as well as selected references from other major phylogenetic groups, ARB, PHYLIP as implemented in ARB; Felsenstein, 1982) and maximum-likelihood (known selected references of $\gamma$-proteobacteria; fastDNAml as implemented in ARB; Maidak et al., 1996) methods on different datasets that varied with respect to the inclusion of variable sequence positions (Ludwig et al., 1998).

\section{RESULTS AND DISCUSSION}

\section{Phenotypic characteristics}

Strains XOM5 and XOM25 $5^{\mathrm{T}}$ are Gram-negative, strictly aerobic and rod-shaped (approx. 1.5-2 $\mu \mathrm{m}$ long $\times 0 \cdot 8-1 \mu \mathrm{m}$ wide); each cell was motile by means of one polar flagellum. The strains grew on MA as regular, opaque colonies that did not swarm or luminesce. They produced a diffusible green to bluegreen pigment when grown in MB (only on the surface) 
or on MA, lecithin and starch media at $13-30{ }^{\circ} \mathrm{C}$, but not at $37^{\circ} \mathrm{C}$. The colour was stable for no longer than $48 \mathrm{~h}$; it then faded. When the strains grew in liquid medium, they formed a compact pellicle on the top of the liquid and no turbidity was observed below the surface.

The isolates were strictly halophilic, requiring seawater-based media for growth; they were unable to grow in STB $\left(10 \mathrm{~g}\right.$ tryptone $\mathrm{l}^{-1}, 3 \mathrm{~g}$ yeast extract $\left.\mathrm{l}^{-1}\right)$ containing $2-4 \% \mathrm{NaCl}$ or supplemented with $0 \cdot 1 \%$ divalent cations $\left(\mathrm{Mg}^{2+}\right.$ and $\left.\mathrm{Ca}^{2+}\right)$ alone or in combination, but showed good growth on MB/MA and Baumann's ASW-based media (Baumann et al., 1984). They were able to grow on MB containing up to $4 \%$ $\mathrm{NaCl}$, but no growth was observed at $\geqslant 6 \% \mathrm{NaCl}$. The organisms were chemo-organotrophs, unable to ferment sugars under anaerobic conditions, as determined on $\mathrm{O} / \mathrm{F}$ medium with half-strength ASW. The catalase and oxidase reactions were positive. Nitrate was not reduced to nitrite. No growth or gas production was observed on Baumann's denitrification medium. The strains grew at temperatures ranging from 13 to $37^{\circ} \mathrm{C}$ but not at 4 or $40^{\circ} \mathrm{C}$. No growth was observed on TCBS agar. No hydrolytic activities were detected on alginate or agar. They hydrolysed gelatin, casein, starch and lecithin. Tween 80 was hydrolysed slightly after prolonged incubation (more than $7 \mathrm{~d}$ ). The strains were negative for the following enzymatic activities: arginine dihydrolase, lysine decarboxylase, ornithine decarboxylase, indole production from tryptophan and sulfite oxidation.

Although the strains were originally reported as being capable of growing without added growth factors (Ortigosa et al., 1994), they are currently unable to grow on basal medium without added yeast extract; thus, the results reported here for nutritional screening were obtained on Bauman's basal medium supplemented with $1 \mathrm{~g}$ yeast extract $\mathrm{l}^{-1}$. The strains used the following compounds as sole carbon and energy sources: cellobiose, amygdalin, propionate, L-tyrosine, L-citrulline, glutamine and histidine. Other carbon sources allowing weak growth were D-glucose, Dfructose, maltose, sucrose, fumarate and L-leucine. Neither of the strains utilized the following substrates: L-arabinose, D-xylose, D-galactose, D-mannose, Lrhamnose, sucrose, lactose, melibiose, salicin, arbutin, D-gluconate, D-glucuronate, D-galacturonate, $N$-acetyl D-glucosamine, saccharate, glycerate, glycerol, Dmannitol, D-sorbitol, $m$-inositol, citrate, aconitate, $\alpha$ ketoglutarate, DL-malate, acetate, DL-lactate, DL- $\beta$ hydroxybutyrate, $p$-hydroxybenzoate, glycine, L-serine, L-threonine, L-glutamate, L-alanine, $\gamma$-aminobutyrate, L-ornithine, sarcosine and putrescine.

\section{Fatty acid composition}

Thirty-one fatty acids, containing 9-20 carbon atoms, were detected in the extracts (Table 1). The predominant fatty acids were straight-chain fatty acids, and only minor quantities of iso-branched fatty acids
Table 1. Cellular fatty acid composition of Thalassomonas viridans strains

Values are percentages of total fatty acid content. The numbers of carbon atoms and double bonds are indicated. The following fatty acids were present at levels of $<1 \%$ in both strains: 10:0, 10:0 3-OH, i11:0 3-OH, 13:0, i12:0

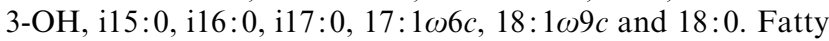
acid 9:0 was present at $<1 \%$ in strain CECT 5082 but was absent from strain CECT $5083^{\mathrm{T}}$. Fatty acids $\mathrm{i} 12: 0$ and 20: $1 \omega 7 c$ were present at $<1 \%$ in strain CECT $5083^{\mathrm{T}}$ but were absent from CECT 5082.

\begin{tabular}{|lcc|}
\hline Fatty acid & CECT 5082 & CECT 5083 $^{\mathbf{T}}$ \\
\hline $11: 0$ & $1 \cdot 10$ & $0 \cdot 90$ \\
$11: 03-\mathrm{OH}$ & $4 \cdot 20$ & $3 \cdot 00$ \\
$12: 0$ & $1 \cdot 56$ & $1 \cdot 97$ \\
$12: 03-\mathrm{OH}$ & $4 \cdot 99$ & $6 \cdot 06$ \\
$13: 03-\mathrm{OH} / \mathrm{i} 15: 1^{*}$ & $1 \cdot 33$ & $0 \cdot 89$ \\
$14: 0$ & $2 \cdot 30$ & $3 \cdot 07$ \\
$15: 1 \omega 8 c$ & $5 \cdot 77$ & $4 \cdot 54$ \\
$15: 1 \omega 6 c$ & $1 \cdot 20$ & $0 \cdot 40$ \\
$15: 0$ & $11 \cdot 14$ & $5 \cdot 96$ \\
$16: 0$ & $11 \cdot 19$ & $13 \cdot 65$ \\
$16: 1 \omega 7 c / \mathrm{i} 152-\mathrm{OH}^{*}$ & $21 \cdot 23$ & $28 \cdot 38$ \\
$17: 1 \omega 8 c$ & $19 \cdot 68$ & $14 \cdot 07$ \\
$17: 0$ & $4 \cdot 71$ & $3 \cdot 11$ \\
$18: 1 \omega 7 c$ & $3 \cdot 18$ & $6 \cdot 12$ \\
\hline
\end{tabular}

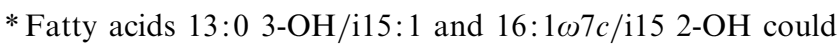
not be separated in the analysis, so the values represent the summed features.

were detected. Saturated and monounsaturated fatty

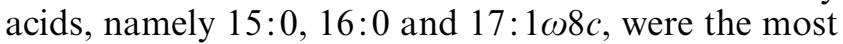
abundant, together with a mixture of $16: 1 \omega 7 c$ and i15:0 2-OH. Hydroxy fatty acids (11:0 3-OH and 12:0 $3-\mathrm{OH})$ were found in both strains in appreciable amounts. Neither of the strains produced polyunsaturated fatty acids.

\section{$\mathbf{G}+\mathbf{C}$ content}

The $\mathrm{G}+\mathrm{C}$ content (determined by the thermal denaturation method) of the DNA of the type strain $\left(\mathrm{XOM} 25^{\mathrm{T}}=\right.$ CECT $\left.5083^{\mathrm{T}}\right)$ was $48 \cdot 4 \mathrm{~mol} \%$.

\section{$16 \mathrm{~S}$ rRNA gene sequencing and phylogenetic analysis}

The almost complete sequences of the 16S rRNA genes were determined for the two strains. Phylogenetic analyses were performed by applying three alternative treeing methods, and the results were congruent with respect to the positioning of the new isolates. The sequences of the two strains were almost identical. There were differences in only two positions.

Comparative analysis of the sequences confirmed the affiliation of the strains to the $\gamma$-Proteobacteria. The next closest (though only moderately related) 


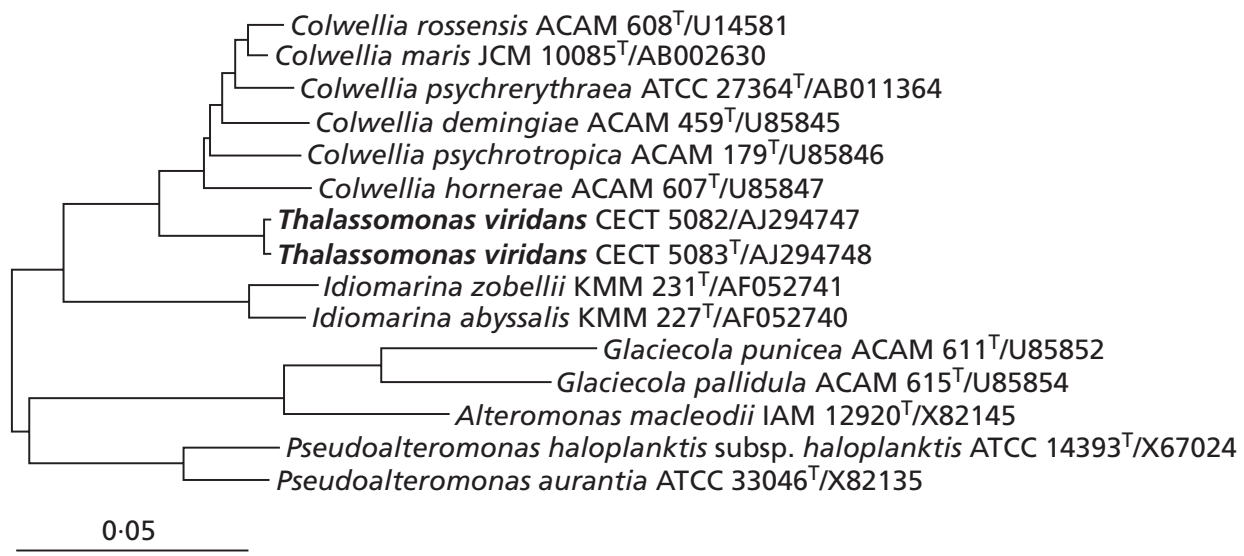

Fig. 1. Phylogenetic tree derived from maximum-parsimony analysis of the $16 \mathrm{~S}$ rRNA gene sequences of Thalassomonas viridans strains CECT $5083^{\top}$ and CECT 5082 and other related genera of the $\gamma$-Proteobacteria. Bar, $5 \%$ estimated sequence divergence.

Table 2. Levels of $16 \mathrm{~S}$ rDNA sequence similarity between Thalassomonas viridans strains CECT 5082 and CECT $5083^{\top}$ and related organisms

\begin{tabular}{|c|c|c|c|c|c|c|c|c|c|c|c|}
\hline Taxon & 1 & 2 & 3 & 4 & 5 & 6 & 7 & 8 & 9 & 10 & 11 \\
\hline \multicolumn{12}{|l|}{ 1. Colwellia rossensis } \\
\hline 2. Colwellia maris & $98 \cdot 2$ & & & & & & & & & & \\
\hline 3. Colwellia psychrerythraea & $97 \cdot 3$ & $97 \cdot 3$ & & & & & & & & & \\
\hline 4. Colwellia demingiae & $96 \cdot 5$ & $96 \cdot 8$ & $96 \cdot 5$ & & & & & & & & \\
\hline 5. Colwellia psychrotropica & $97 \cdot 6$ & $97 \cdot 8$ & $95 \cdot 8$ & $95 \cdot 7$ & & & & & & & \\
\hline 6. Colwellia hornerae & $96 \cdot 6$ & $97 \cdot 0$ & $96 \cdot 1$ & $95 \cdot 5$ & $95 \cdot 8$ & & & & & & \\
\hline 7. Thalassomonas viridans CECT 5082 & 93.5 & 94.2 & $94 \cdot 6$ & 94.9 & $93 \cdot 3$ & $94 \cdot 2$ & & & & & \\
\hline 8. Thalassomonas viridans $\mathrm{CECT} 5083^{\mathrm{T}}$ & $93 \cdot 4$ & $94 \cdot 1$ & 94.5 & 94.8 & $93 \cdot 2$ & $94 \cdot 1$ & 99.9 & & & & \\
\hline 9. Idiomarina zobellii & $89 \cdot 7$ & $90 \cdot 2$ & $89 \cdot 8$ & $90 \cdot 0$ & $90 \cdot 6$ & $90 \cdot 1$ & 90.6 & $90 \cdot 6$ & & & \\
\hline 10. Idiomarina abyssalis & $89 \cdot 8$ & $90 \cdot 3$ & $89 \cdot 9$ & $90 \cdot 0$ & $90 \cdot 6$ & $90 \cdot 0$ & 90.6 & 90.5 & $96 \cdot 9$ & & \\
\hline 11. Glaciecola punicea & $85 \cdot 6$ & $85 \cdot 6$ & $85 \cdot 8$ & $85 \cdot 4$ & $85 \cdot 3$ & $85 \cdot 6$ & $85 \cdot 1$ & 85.0 & $85 \cdot 9$ & $85 \cdot 8$ & \\
\hline 12. Glaciecola pallidula & $86 \cdot 8$ & $87 \cdot 7$ & $87 \cdot 6$ & $87 \cdot 3$ & $87 \cdot 2$ & $86 \cdot 9$ & 86.6 & 86.5 & $86 \cdot 6$ & $86 \cdot 2$ & $91 \cdot 6$ \\
\hline
\end{tabular}

neighbours were Colwellia species (Fig. 1). The corresponding overall $16 \mathrm{~S}$ rRNA sequence similarity values are indicated in Table 2 . The range of $16 \mathrm{~S}$ rRNA gene sequence similarity values to Colwellia species was $93 \cdot 2-94 \cdot 8 \%$, the highest similarity being shown by the Colwellia demingiae sequence. The Colwellia assemblage contains several other marine genera, including Idiomarina and Glaciecola. The sequence similarity was $90 \cdot 5-90 \cdot 6 \%$ to Idiomarina species and $85 \cdot 0-86 \cdot 6 \%$ to members of the genus Glaciecola.

\section{Conclusions}

Two strains of heterotrophic marine bacteria were isolated from Mediterranean oysters (Ostrea edulis) cultivated off the coast near Valencia (Spain). The organisms were strictly aerobic, halophilic, negative in the oxidation/fermentation test, green-pigmented, motile, oxidase- and catalase-positive, Gram-negative rods with a DNA $\mathrm{G}+\mathrm{C}$ content of $48.4 \mathrm{~mol} \%$. It is evident from the phylogenetic analysis and the $16 \mathrm{~S}$ rDNA sequence similarity to other species $(94.8 \%$ or less) that the two isolates represent a separate group amongst the $\gamma$-Proteobacteria, moderately related to the genera Alteromonas, Colwellia, Glaciecola, Idiomarina and Pseudoalteromonas. They can be differentiated phenotypically from these organisms by the traits reported in Table 3. Members of Idiomarina differ from our isolates by the absence of pigmentation, the ability to grow at $4{ }^{\circ} \mathrm{C}$, salinity requirements and, notably, the fact that they are rich in iso-branched fatty acids. Representatives of the genus Colwellia differ notably from our isolates in that they possess a lower $\mathrm{G}+\mathrm{C}$ ratio (approx. 10\% lower), have a fermentative metabolism, reduce nitrates to nitrites, are strict psychrophilic bacteria and produce polyunsaturated fatty acids. It is concluded, therefore, that the oyster isolates can be separated from other described marine bacterial species by using a combi- 
Table 3. Characteristics that distinguish Thalassomonas viridans gen. nov., sp. nov. from other heterotrophic, oxidative, marine genera

Data are from the following references: Baumann et al. (1972), Bowman et al. (1998a, b), Deming et al. (1988), Holmström et al. (1998), Ivanova et al. (2000), Raguénès et al. (1997), Yumoto et al. (1998). Species are indicated as: 1, Thalassomonas viridans; 2 , Colwellia psychrerythraea; 3 , Colwellia demingiae; 4, Colwellia hornerae; 5, Colwellia rossensis; 6, Colwellia psychrotrophica; 7 , Colwellia maris; 8, Alteromonas macleodii; 9, 'Alteromonas infernus'; 10, Glaciecola punicea; 11, Glaciecola pallidula; 12, Pseudoalteromonas tunicata; 13, Idiomarina abyssalis; 14, Idiomarina zobellii. Characteristics are scored as: +, positive; - , negative; ND, no data available; NG, no growth; TR, trace amounts of fatty acid $(<0 \cdot 1 \%$ of total fatty acid content $)$; v, variable response. PUFA, Polyunsaturated fatty acids.

\begin{tabular}{|c|c|c|c|c|c|c|c|c|c|c|c|c|c|c|}
\hline Characteristic & 1 & 2 & 3 & 4 & 5 & 6 & 7 & 8 & 9 & 10 & 11 & 12 & 13 & 14 \\
\hline Pigment & Green & Red & - & - & - & - & - & - & - & Red & Pink & Green & - & - \\
\hline Growth in $6 \% \mathrm{NaCl}$ & - & ND & - & - & - & + & ND & + & + & + & + & + & + & + \\
\hline Growth at $4{ }^{\circ} \mathrm{C}$ & - & + & + & + & + & + & + & - & - & + & + & + & + & + \\
\hline Growth at $30^{\circ} \mathrm{C}$ & + & - & - & - & - & - & - & + & + & - & - & ND & + & + \\
\hline Fermentative on carbohydrates* & $-{ }^{\mathrm{a}}$ & $+{ }^{\mathrm{b}}$ & $+{ }^{c}$ & $+{ }^{\mathrm{d}}$ & $+{ }^{\mathrm{a}}$ & $+{ }^{c}$ & - & - & - & - & - & - & - & - \\
\hline \multicolumn{15}{|l|}{ Hydrolysis of: } \\
\hline Gelatin & + & $\mathrm{V}$ & - & - & - & - & + & + & + & - & - & + & + & + \\
\hline Tween $80 \dagger$ & - & + & - & + & NG & + & + & + & ND & $\mathrm{V}$ & + & ND & + & + \\
\hline Nitrate reduction & - & + & + & + & + & + & + & - & - & - & - & ND & ND & ND \\
\hline \multicolumn{15}{|l|}{ Use of: } \\
\hline D-Fructose & + & - & - & - & + & - & - & + & + & - & - & - & - & - \\
\hline Maltose & + & - & - & - & - & - & - & + & + & - & - & + & - & - \\
\hline Sucrose & + & - & - & - & - & - & - & + & + & - & - & - & - & - \\
\hline D-Xylose, galactose & - & - & - & - & - & - & - & + & + & - & - & - & ND & ND \\
\hline Melibiose, D-mannitol & - & - & - & - & - & - & - & + & + & - & - & - & - & - \\
\hline D-Gluconate & - & - & - & - & + & - & ND & + & + & - & - & ND & ND & ND \\
\hline Glycerol & - & - & - & + & + & - & - & + & + & - & + & - & $+t$ & - \\
\hline Acetate & - & + & + & + & + & + & + & + & ND & - & + & ND & + & ND \\
\hline L-Aconitate & - & + & + & + & + & + & ND & $\mathrm{V}$ & ND & - & + & ND & ND & ND \\
\hline L-Alanine & - & & $\mathrm{V}$ & & + & + & ND & + & ND & - & - & ND & + & + \\
\hline \multicolumn{15}{|l|}{ Fatty acids ( $\%$ of total): } \\
\hline i1 $15: 0$ & $<1 \cdot 0$ & - & - & - & - & - & ND & ND & ND & ND & ND & ND & $33 \cdot 7$ & $40 \cdot 6$ \\
\hline i17:0 & $<1 \cdot 0$ & $<1 \cdot 0$ & $<1 \cdot 0$ & $<1 \cdot 0$ & $<1 \cdot 0$ & $<1 \cdot 0$ & ND & ND & ND & ND & ND & ND & $11 \cdot 9$ & $12 \cdot 5$ \\
\hline $17: 1 \omega 8 c$ & $14-19 \cdot 7$ & $0-1 \cdot 3$ & TR & $5 \cdot 6$ & $<1 \cdot 0$ & $4 \cdot 5$ & ND & ND & ND & ND & ND & ND & $<1 \cdot 0$ & $1 \cdot 1$ \\
\hline PUFA & - & $5 \cdot 5-9 \cdot 5$ & $1 \cdot 7-2 \cdot 2$ & $4 \cdot 1$ & $6 \cdot 0$ & $<1 \cdot 0$ & ND & ND & ND & ND & ND & ND & - & - \\
\hline DNA G $+\mathrm{C}$ content $(\mathrm{mol} \%)$ & $48 \cdot 4$ & $35-38$ & 37 & 39 & 38 & 42 & $39 \cdot 4$ & $44-47$ & $48 \cdot 1$ & $44-46$ & 40 & $42-43$ & $50 \cdot 4$ & 48 \\
\hline
\end{tabular}

* Fermentative metabolism on D-glucose, $N$-acetylglucosamine and glycerol (a), D-glucose and $N$-acetylglucosamine (b), $N$ acetylglucosamine (c) or glycerol (d) is indicated.

$\uparrow$ After less than $7 \mathrm{~d}$ of incubation.

$\$$ Genus description gives contradictory results for this trait (Ivanova et al., 2000).

nation of phenotypic characteristics. Thus, we propose the creation of a new genus, Thalassomonas gen. nov., containing strains XOM5 and XOM $25^{\mathrm{T}}$ as Thalassomonas viridans sp. nov.

\section{Description of Thalassomonas gen. nov.}

Thalassomonas (Tha.las'so.mo.nas. Gr. n. Thalasso the sea; Gr. n. monas a unit; N.L. n. Thalassomonas a monad from the sea).

Gram-negative, strictly aerobic, chemo-organotrophic, halophilic bacteria. Oxidase- and catalasepositive, motile by single polar flagella. Cells are rodshaped and approximately $1 \cdot 5-2 \mu \mathrm{m}$ long and $0 \cdot 8-1$ $\mu \mathrm{m}$ wide. No growth without sea water or the addition of combined marine salts to the medium. Mesophilic. The temperature range for growth is $13-37^{\circ} \mathrm{C}$; no growth at 4 or $40^{\circ} \mathrm{C}$. Gelatin, casein, starch and lecithin, but not alginate or agar, are hydrolysed. Nitrate is not reduced to nitrite. Sulfite is not oxidized. Arginine dihydrolase, lysine decarboxylase, ornithine decarboxylase and indole-production activities are not detected. The predominant cellular fatty acids are saturated and monounsaturated straight-chain fatty acids. The DNA $\mathrm{G}+\mathrm{C}$ content of the type strain of the type species, CECT $5083^{\mathrm{T}}\left(=\mathrm{XOM} 25^{\mathrm{T}}\right)$, is $48.4 \mathrm{~mol} \%$. The genus is affiliated to the $\gamma$ Proteobacteria and contains one species, Thalassomonas viridans, which is the type species. 


\section{Description of Thalassomonas viridans sp. nov.}

Thalassomonas viridans (vi.ri'dans. L. adj. viridans green).

In addition to the characteristics that define the genus, it has the characteristics described below. Strains grow on MA as regular, opaque colonies that produce a green/blue-green, unstable, diffusible pigment. They grow in $\mathrm{MB}$ with $2-4 \% \mathrm{NaCl}$ but not with $6 \%$ or more. No growth is observed in STB $2-4 \% \mathrm{NaCl}$, in STB 2-4\% $\mathrm{NaCl}$ plus $\mathrm{MgCl}_{2}$, in STB $2 \% \mathrm{NaCl}$ plus $\mathrm{CaCl}_{2}$ or in $\mathrm{STB} 2 \% \mathrm{NaCl}$ plus $\mathrm{MgCl}_{2}$ and $\mathrm{CaCl}_{2}$. Strains hydrolyse Tween 80 only after prolonged incubation (more than $7 \mathrm{~d}$ ). Organic growth factors are required. Strains are able to grow on basal medium supplemented with $0 \cdot 1 \mathrm{~g}$ yeast extract $1^{-1}$, using the following compounds as sole carbon and energy sources: cellobiose, amygdalin, propionate, L-tyrosine, L-citrulline, glutamine and histidine. Growth is weak on D-glucose, D-fructose, maltose, sucrose, fumarate and L-leucine. Neither of the strains utilizes the following substrates: L-arabinose, D-xylose, D-galactose, D-mannose, L-rhamnose, sucrose, lactose, melibiose, salicin, arbutin, D-gluconate, Dglucuronate, D-galacturonate, $N$-acetyl D-glucosamine, saccharate, glycerate, glycerol, D-mannitol, D-sorbitol, $m$-inositol, citrate, aconitate, $\alpha$-ketoglutarate, DL-malate, acetate, DL-lactate, $p$-hydroxybenzoate, glycine, L-serine, L-glutamate, L-alanine, $\gamma$ aminobutyrate, sarcosine and putrescine. The major

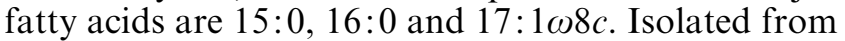
oysters harvested on the Mediterranean coast of Vinaroz, Spain.

The type strain, XOM $25^{\mathrm{T}}\left(=\mathrm{CECT} 5083^{\mathrm{T}}=\mathrm{DSM}\right.$ $13754^{\mathrm{T}}$ ), was isolated from oyster homogenate. The species also includes strain XOM5 (= CECT $5082=$ DSM 13753). The type strain XOM $25^{\mathrm{T}}$ differs from XOM5 by the following traits: it is able to use Dribose, succinate, DL- $\beta$-hydroxybutyrate, L-threonine, L-arginine and L-ornithine as sole carbon and energy sources.

\section{ACKNOWLEDGEMENTS}

We are most grateful to A. Ventosa and M. C. Márquez, Universidad de Sevilla, Spain, for the DNA G + C content determinations.

\section{REFERENCES}

Baumann, P. \& Baumann, L. (1981). The marine gram-negative eubacteria: genera Photobacterium, Beneckea, Alteromonas, Pseudomonas and Alcaligenes. In The Prokaryotes, vol. 2, pp. 1302-1331. Edited by M. P. Starr, H. Stolp, H. G. Trüper, A. Balows \& H. Schlegel. Berlin: Springer.

Baumann, L., Baumann, P., Mandel, M. \& Allen, R. D. (1972). Taxonomy of aerobic marine eubacteria. J Bacteriol 110, 402-429.

Baumann, P., Gauthier, M. J. \& Baumann, L. (1984). Genus Alteromonas Baumann, Baumann, Mandel and Allen 1972. In Bergey's Manual of Systematic Bacteriology, vol. 1, pp. 343-352.
Edited by N. R. Krieg \& J. G. Holt. Baltimore: Williams \& Wilkins.

Bowman, J.P., Gosink, J. J., McCammon, S. A., Lewis, T. E., Nichols, D. S., Nichols, P. D., Skerratt, J. H., Staley, J. T. \& McMeekin, T. A. (1998a). Colwellia demingiae sp. nov., Colwellia hornerae sp. nov., Colwellia rossensis sp. nov. and Colwellia psychrotropica sp. nov.: psychrophilic Antarctic species with the ability to synthesize docosahexaenoic acid (22:6w3). Int $J$ Syst Bacteriol 48, 1171-1180.

Bowman, J. P., McCammon, S. A., Brown, J. L. \& McMeekin, T. A. (1998b). Glaciecola punicea gen. nov., sp. nov. and Glaciecola pallidula gen. nov., sp. nov.: psychrophilic bacteria from Antarctic sea-ice habitats. Int J Syst Bacteriol 48, 1213-1222.

Brosius, J., Dull, T. J., Sleeter, D. D. \& Noller, H. F. (1981). Gene organization and primary structure of a ribosomal RNA operon from Escherichia coli. J Mol Biol 148, 107-127.

Buck, J. D. (1982). Nonstaining $(\mathrm{KOH})$ method for determination of Gram reactions of marine bacteria. Appl Environ Microbiol 44, 992-993.

Deming, J. W., Somers, L. K., Straube, W. L., Swartz, D. G. \& MacDonell, M. T. (1988). Isolation of an obligately barophilic bacterium and description of a new genus, Colwellia gen. nov. Syst Appl Microbiol 10, 152-160.

Felsenstein, J. (1982). Numerical methods for inferring phylogenetic trees. $Q$ Rev Biol 57, 379-404.

González, J. M., Kiene, R. P. \& Moran, M. A. (1999). Transformation of sulfur compounds by an abundant lineage of marine bacteria in the $\alpha$-subclass of the class Proteobacteria. Appl Environ Microbiol 65, 3810-3819.

Heimbrook, M. E., Wang, W. L. L. \& Campbell, G. (1989). Staining bacterial flagella easily. J Clin Microbiol 27, 2612-2615.

Holmström, C. \& Kjelleberg, S. (1999). Marine Pseudoalteromonas species are associated with higher organisms and produce biologically active extracellular agents. FEMS Microbiol Ecol 30, 285-293.

Holmström, C., Rittschof, D. \& Kjelleberg, S. (1992). Inhibition of settlement by larvae of Balanus amphitrite and Ciona intestinalis by a surface-colonizing marine bacterium. Appl Environ Microbiol 58, 2111-2115.

Holmström, C., James, S., Neilan, B. A., White, D. C. \& Kjelleberg, S. (1998). Pseudoalteromonas tunicata sp. nov., a bacterium that produces antifouling agents. Int J Syst Bacteriol 48, 1205-1212.

Ivanova, E. P., Romanenko, L. A., Chun, J. \& 7 other authors. (2000). Idiomarina gen. nov., comprising novel indigenous deepsea bacteria from the Pacific Ocean, including descriptions of two species, Idiomarina abyssalis sp. nov. and Idiomarina zobellii sp. nov. Int J Syst Evol Microbiol 50, 901-907.

Kämpfer, P. \& Kroppenstedt, R. M. (1996). Numerical analysis of fatty acid patterns of coryneform bacteria and related taxa. Can J Microbiol 42, 989-1005.

Lee, J. V. \& Donovan, T. J. (1985). Vibrio, Aeromonas and Plesiomonas. In Isolation and Identification of Microorganisms of Medical and Veterinary Importance, pp. 13-33. Society for Applied Bacteriology Technical Series no. 21. Edited by C. H. Collins \& J. M. Grange. London: Academic Press.

Lemos, M. L., Dopazo, C. P., Toranzo, A. E. \& Barja, J. L. (1991). Competitive dominance of antibiotic-producing marine bacteria in mixed cultures. J Appl Bacteriol 71, 228-232.

Lewington, J. S. D., Greenaway, B. J. \& Spillane, B. J. (1987). Rapid small scale preparation of bacterial genomic DNA suitable for cloning and hybridization analysis. Lett Appl Microbiol 5, 51-53. 
Ludwig, W. \& Strunk, O. (1997). ARB: a software environment for sequence data. http://www.mikro.biologie.tu-muenchen.de/ pub/ARB/documentation/arb.ps

Ludwig, W., Strunk, O., Klugbauer, S., Klugbauer, N., Weizenegger, M., Neumaier, J., Bachleitner, M. \& Schleifer, K.-H. (1998). Bacterial phylogeny based on comparative sequence analysis. Electrophoresis 19, 554-568.

Maidak, B. L., Olsen, G. J., Larsen, N., Overbeek, R., McCaughey, M. J. \& Woese, C. R. (1996). The Ribosomal Database Project (RDP). Nucleic Acids Res 24, 82-85.

Marmur, J. \& Doty, P. (1962). Determination of the base composition of deoxyribonucleic acid from its thermal denaturation temperature. J Mol Biol 5, 109-118.

Ortigosa, M., Garay, E. \& Pujalte, M. J. (1994). Numerical taxonomy of aerobic, Gram-negative bacteria associated with oysters and surrounding seawater of the Mediterranean coast. Syst Appl Microbiol 17, 589-600.

Owen, R. J. \& Pitcher, D. (1985). Current methods for estimating
DNA base composition and levels of DNA-DNA hybridization. In Chemical Methods in Bacterial Systematics, pp. 67-93. Edited by M. Goodfellow \& E. Minnikin. London: Academic Press.

Raguénès, G. H. C., Peres, A., Ruimy, R., Pignet, P., Christen, R., Loaec, M., Rougeaux, H., Barbier, G. \& Guezennec, J. G. (1997). Alteromonas infernus sp. nov., a new polysaccharide-producing bacterium isolated from a deep-sea hydrothermal vent. $J$ Appl Microbiol 82, 422-430.

Smibert, R. M. \& Krieg, N. R. (1994). Phenotypic characterization. In Methods for General and Molecular Bacteriology, pp. 607-654. Edited by P. Gerhardt, R. G. E. Murray, W. A. Wood \& N. R. Krieg. Washington, DC: American Society for Microbiology.

Yumoto, I., Kawasaki, K., Iwata, H., Matsuyama, H. \& Okuyama, H. (1998). Assignment of Vibrio sp. strain ABE-1 to Colwellia maris sp. nov., a new psychrophilic bacterium. Int $J$ Syst Bacteriol 48, 1357-1362. 